\title{
Evaluation of Link and Match Policies in Private Universities in Indonesia in Terms of the Workplace of Graduates
}

\author{
Andri Eko Prabowo \\ Universitas Negeri Malang \\ Wahjoedi \\ Universitas Negeri Malang \\ Sugeng Hadi Utomo \\ Universitas Negeri Malang \\ Agung Haryono \\ Universitas Negeri Malang
}

This study aims to see the effectiveness of link and match policies by looking at the workplaces of private higher education graduates in Indonesia. The research was conducted online in May-December 2017-2019. Descriptive analysis is used to obtain results that describe the actual conditions. The results of the study indicate that the link and match policy in terms of graduate work placement has been effective in private universities in Indonesia. This success is shown by the increase in the absorption of graduates in the world of work, the trend of increasing the vertical and horizontal alignment of graduates. This study also found that the choice of workplaces for graduates of private universities were companies, government agencies, and then NGOs. While entrepreneurship is the last choice for graduates of private universities in Indonesia.

Keywords: link and match, workplace, private colleges

\section{INTRODUCTION}

Globalization and the industrial revolution that penetrated the fields of information technology, science and robotics have had a major impact on the world of work. These changes require higher education to anticipate and evaluate the competencies needed by the world of work. Continuous evaluation is also necessary to obtain feedback from users and graduates, and to reduce the gap between the world of education and the business world. The dynamics of the competency gap between the business world and higher education have long received worldwide attention and been studied by several researchers, such as working conditions and employment (Enders \& Teichler, 1997) higher education and the world of work (Teichler, 1999), an overview of higher education and the world of work (Kogan \& Brennan, 1993), the impact of education policy (Higher Education and the World of Work, 2015). 
The main dynamics of the business world with education occur in the increase in educated unemployment, both open and hidden unemployment as a result of the increase in the number of college graduates, changes in socio-economic and political conditions that affect the world job market. (Supriati \& Handayani, 2018). In addition, the rapid development of science and information and communication technology has also led to fundamental changes in competencies, qualifications, and requirements for obtaining employment. Manpower problems involve many aspects of life, so it requires a strategic national policy to address labor problems.

Data released by the Badan Pusat Statistik (BPS) shows that the number of open unemployed undergraduate graduates from August 2018 to February 2019 has increased by 90000 people (Badan Pusat Statistik, 2019), which means there is an increase of more than 10000 people every month. This condition needs serious attention, considering that currently many companies are rationalizing the number of workers as an effect of the economic downturn caused by the corona virus pandemic.

Competency-oriented higher education that is run by the government through a link and match policy currently focuses on the ability of graduates to meet the needs of the world of work (Disas, 2018). This policy is implemented by higher education institutions through the implementation of an output-based curriculum, namely a curriculum that is structured based on the needs of the labor market. The implementation of the link and match policy is expected to reduce the number of unemployed generated by universities.

The link and match policy is implemented to put the function and position of the education system in particular with regard to employment (Robst, 1995). The application of this policy in the higher education curriculum is then evaluated through the absorption of graduates in the world of work(Nature, 2016). So, to find out the success of implementing the link and match policy, it is done by looking at the absorption capacity of graduates in the world of work.

The absorption capacity of graduates in the world of work is not only seen from the time it takes for graduates to get a job, but also from the alignment of graduates with their work. (Fikawati, 2018). The combination of time and harmony in observing the absorption capacity of graduates is expected to provide a comprehensive picture of the effectiveness of the implementation of link and match policies in private universities in Indonesia. This research was conducted to evaluate the effectiveness of implementing the link and match policy, which is focused on where graduates work within 2 years after graduating from college.

\section{RESEARCH METHODS}

This type of research is a survey research. Research was conducted online by adapting the official questionnaire from the government, namely the questionnaire issued by KEMRISTEKDIKTI Republic of Indonesia on points number F11, F14, and F15. The sample in this study were private university graduates who had graduated 2 years earlier. The choice of 2 years after graduation is based on the consideration that the first year after graduation is a post-study transition period and graduates do not have a permanent job (Fikawati, 2018). At 2 years after graduating, graduates generally have a steady and steady job(Ahmad, 2017). Sampling was carried out by the snowball random sampling method on graduates of private universities in Indonesia. The research was conducted for three years in May - July of the current year from 2017-2019. The research data were analyzed descriptively quantitatively.

\section{RESULTS}

\section{Respondent Profile}

Respondents in this study were graduates of private universities in 2015-2017. The selection of respondents was based on a circular letter from the Director General of Belmawa Kemristekdikti No. 471 / B / SE / VII / 2017 concerning the implementation of tracer studies in tertiary institutions. The distribution of respondents in this study can be seen in the following table: 
TABLE 1

RESEARCH RESPONDENTS

\begin{tabular}{lllll}
\hline Graduation year & Research Year & $\begin{array}{l}\text { Number of } \\
\text { respondents }\end{array}$ & Work & percentage \\
\hline 2015 & 2017 & 819 & 460 & $56.17 \%$ \\
2016 & 2018 & 1151 & 606 & $52.65 \%$ \\
2017 & 2019 & 1033 & 981 & $94.97 \%$ \\
Total Respondents & 3003 & 2047 & $68.17 \%$ \\
\hline
\end{tabular}

The total number of respondents involved in this study was 3003 people, with the number getting smaller and smaller. This is due to the breakdown of communication between graduates of private universities. The research data shows that there are 2047 people or $68.17 \%$ who already have permanent jobs, either working as government employees, private companies, or working by building their own companies (entrepreneurship).

\section{Graduate Work Profile}

Private universities generally do brand through the number of graduates who work. This condition encourages private universities to compile a curriculum tailored to the needs of the world of work at that time. The results showed that more than $65 \%$ of graduates from private university undergraduate programs chose to work at various institutions both public and private, and there were about $20 \%$ of graduates who chose to become entrepreneurs. More details can be seen in the following table.

TABLE 2

\section{WORK STATUS GRADUATES}

\begin{tabular}{lllllllll}
\hline \multirow{2}{*}{ Status } & \multicolumn{3}{l}{ Graduation year } & \multicolumn{3}{c}{ total } \\
\cline { 2 - 8 } & 2015 & $\%$ & 2016 & $\%$ & 2017 & $\%$ & $\sum$ & $\%$ \\
\hline Work & 362 & $78.7 \%$ & 475 & $78.4 \%$ & 568 & $57.9 \%$ & 1405 & $68.6 \%$ \\
Entrepreneur & 91 & $19.8 \%$ & 42 & $6.9 \%$ & 323 & $32.9 \%$ & 456 & $22.3 \%$ \\
Others & 7 & $1.5 \%$ & 89 & $14.7 \%$ & 90 & $9.2 \%$ & 186 & $9.1 \%$ \\
\cline { 1 - 6 } Total & 460 & & 606 & & 981 & & 2049 & \\
\hline
\end{tabular}

\section{FIGURE 1 \\ WORK STATUS GRADUATES}

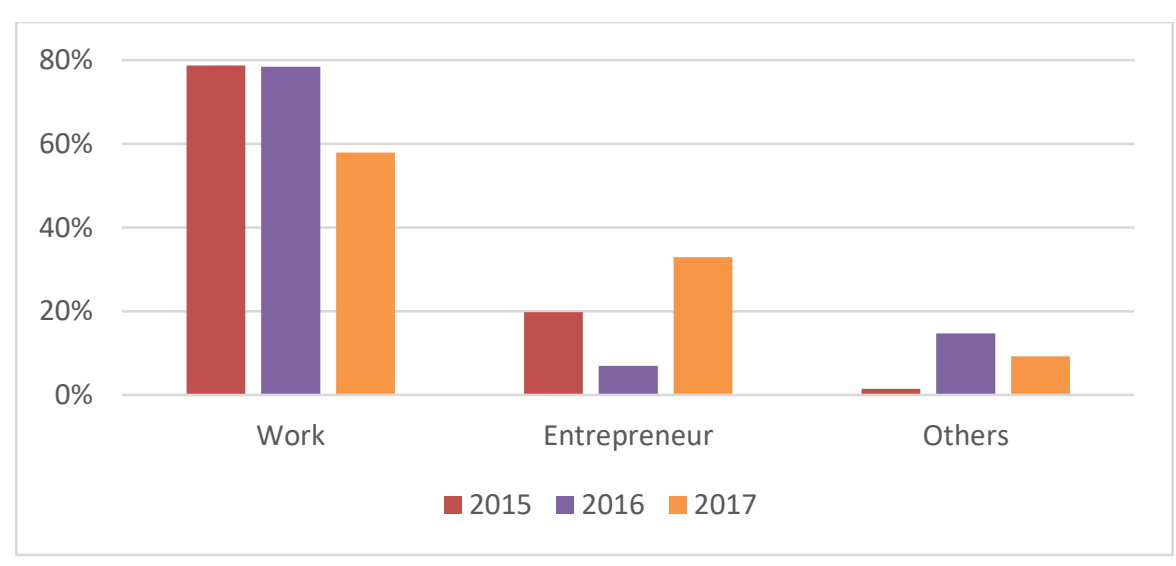


Tables and graphs of graduate employment status show that graduates who choose to work for various government, private and NGO institutions have a downward trend. Then the results of the analysis also show that the choice to become self-employed shows an increasing trend. This condition is in line with the results of the Asia Pacific Entrepreneurship Survey research in April 2019 which states that 96\% of Indonesians have a strong desire to become entrepreneurs (Herbalife Survey, 2019).

\section{Graduate Workplace Profile}

The large number of private university graduates who choose to work after completing their education requires further analysis regarding where these graduates work. The results of data analysis show that the workplace for graduates is dominated by private companies, followed by government agencies. Community Social Institutions receive less attention from PTS graduates.

\section{FIGURE 2 \\ WORKPLACE GRADUATES}

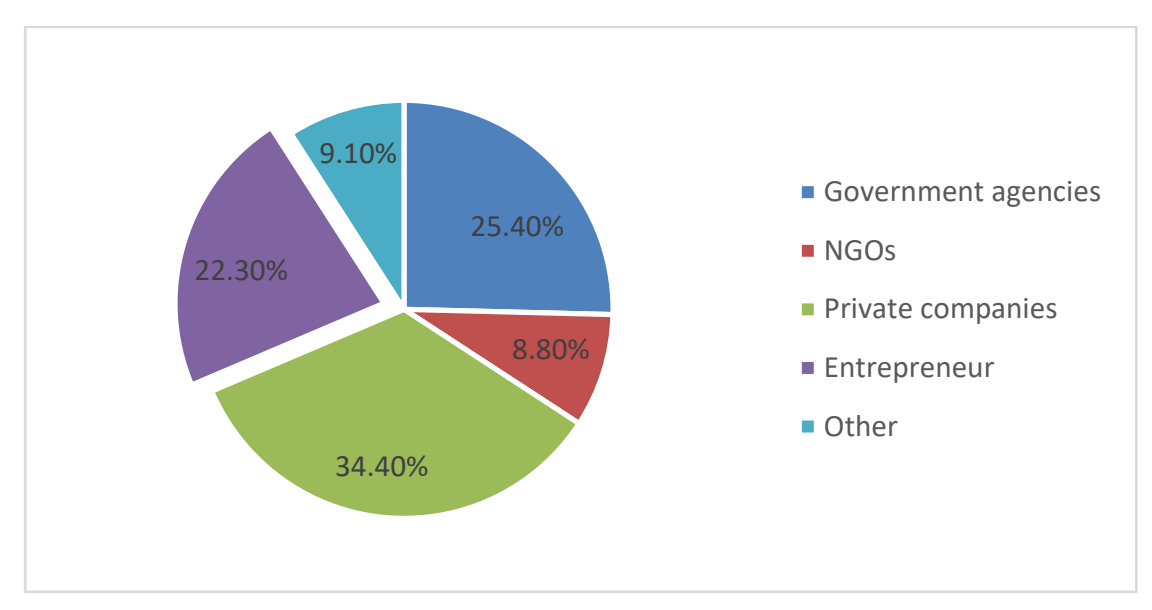

TABLE 3

WORKPLACE DISTRIBUTION

\begin{tabular}{llllll}
\hline & \multicolumn{3}{l}{ Graduation year } & \multicolumn{2}{l}{ total } \\
\cline { 2 - 6 } & 2015 & 2016 & 2017 & $\sum$ & $\%$ \\
\cline { 2 - 6 } Government agencies & 222 & 223 & 75 & 520 & $25.4 \%$ \\
NGOs & 11 & 162 & 8 & 181 & $8.8 \%$ \\
Private companies & 129 & 90 & 485 & 704 & $34.4 \%$ \\
Entrepreneur & 91 & 42 & 323 & 456 & $22.3 \%$ \\
Other & 7 & 89 & 90 & 186 & $9.1 \%$ \\
& 460 & 606 & 981 & 2047 & \\
\hline
\end{tabular}


FIGURE 3

DISTRIBUTION OF GRADUATE WORKPLACES BY YEAR

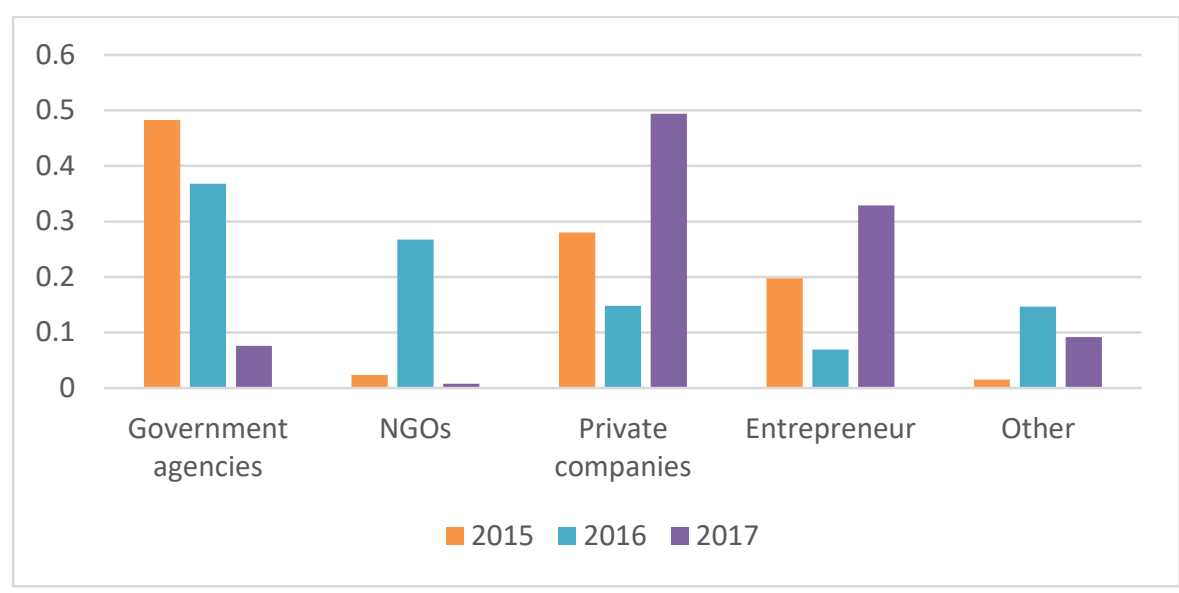

The results of the analysis of graduate workplace data show that working for private companies and government institutions dominates the choice of graduates. However, the percentage of graduates who work in government institutions shows a decreasing trend. Then the choice of working for a private company shows the opposite direction, which is an increasing trend. Meanwhile, the trend of working for community social institutions tends to fluctuate.

The decline in the trend of working for government institutions was due to the decline in civil servant vacancies opened by the government in recent years. Then on the other hand, information on job vacancies at private companies is widely circulating on social media and alumni networks distributed by career center institutions at each university. Meanwhile, the ups and downs of graduates who work in community social institutions are more due to factors of income and career paths at these institutions.

\section{Vertical Alignment}

Vertical alignment is the suitability of a graduate's job compared to the level of education. This vertical alignment is implicitly able to describe the ability of graduates to do work in accordance with the competencies expected by the institution where they work.

TABLE 4 VERTICAL ALIGNMENT

\begin{tabular}{lllllll}
\hline \multirow{2}{*}{ Competence of graduates } & \multicolumn{6}{l}{ Graduation year } \\
\cline { 2 - 7 } & 2015 & & 2016 & & 2017 & \\
\cline { 2 - 7 } & $\sum$ & $\%$ & $\sum$ & $\%$ & $\sum$ & $\%$ \\
\hline higher & 27 & $6.1 \%$ & 53 & $8.6 \%$ & 127 & $15.1 \%$ \\
same & 131 & $29.6 \%$ & 289 & $46.7 \%$ & 593 & $70.5 \%$ \\
lower & 285 & $64.3 \%$ & 277 & $44.7 \%$ & 57 & $6.8 \%$ \\
Senior High School & 0 & $0.0 \%$ & 0 & $0.0 \%$ & 64 & $7.6 \%$ \\
\cline { 2 - 7 } & 443 & & 619 & & 841 & \\
\hline
\end{tabular}


FIGURE 4

VERTICAL ALIGNMENT

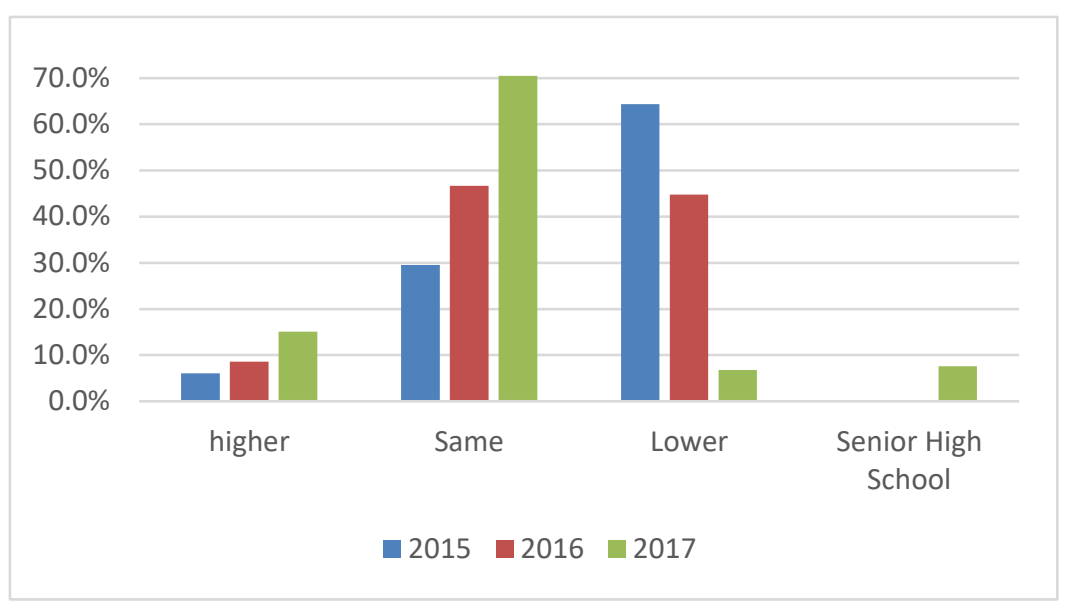

The results of the data analysis show that the number of graduates who work at a higher position and in the same position as their education level is experiencing an increasing trend every year. Meanwhile, job positions lower than the level of education have a downward trend. However, the results of the 2019 tracer on the 2017 graduates show that job positions that just need senior high school education expertise have increased significantly.

The increase in the number of graduates working in positions without requiring higher education is explicitly a decrease in the quality of education. However, if it is examined more deeply, by looking at the increasing number of entrepreneurial alumni, it is possible that the increasing number of graduates working in these positions will come from graduates who are entrepreneurs by starting new types of businesses. This implicitly proves the increasing quality of education in private universities in Indonesia.

\section{Horizontal Alignment}

Horizontal alignment is the suitability of the field of work with the study program. This alignment implicitly shows the suitability of the competence in the field of science of graduates with the needs of the workforce.

TABLE 5

HORIZONTAL ALIGNMENT

\begin{tabular}{lllllll}
\hline \multirow{2}{*}{$\begin{array}{l}\text { Competence Relationship } \\
\text { of Graduates with the } \\
\text { world of work }\end{array}$} & \multicolumn{5}{l}{ Graduation year } \\
\cline { 2 - 7 } & 2015 & $\%$ & $\sum$ & $\%$ & $\sum$ & $\%$ \\
\cline { 2 - 7 } very closely & 161 & $36.3 \%$ & 205 & $33.2 \%$ & 306 & $36.4 \%$ \\
tightly & 53 & $11.9 \%$ & 76 & $12.3 \%$ & 118 & $14.0 \%$ \\
pretty tight & 73 & $16.4 \%$ & 130 & $21.0 \%$ & 201 & $23.9 \%$ \\
less tight & 78 & $17.6 \%$ & 99 & $16.0 \%$ & 77 & $9.2 \%$ \\
not at all & 79 & $17.8 \%$ & 108 & $17.5 \%$ & 138 & $16.4 \%$ \\
& 444 & & 618 & & 840 & \\
\hline
\end{tabular}


FIGURE 5

HORIZONTAL ALIGNMENT

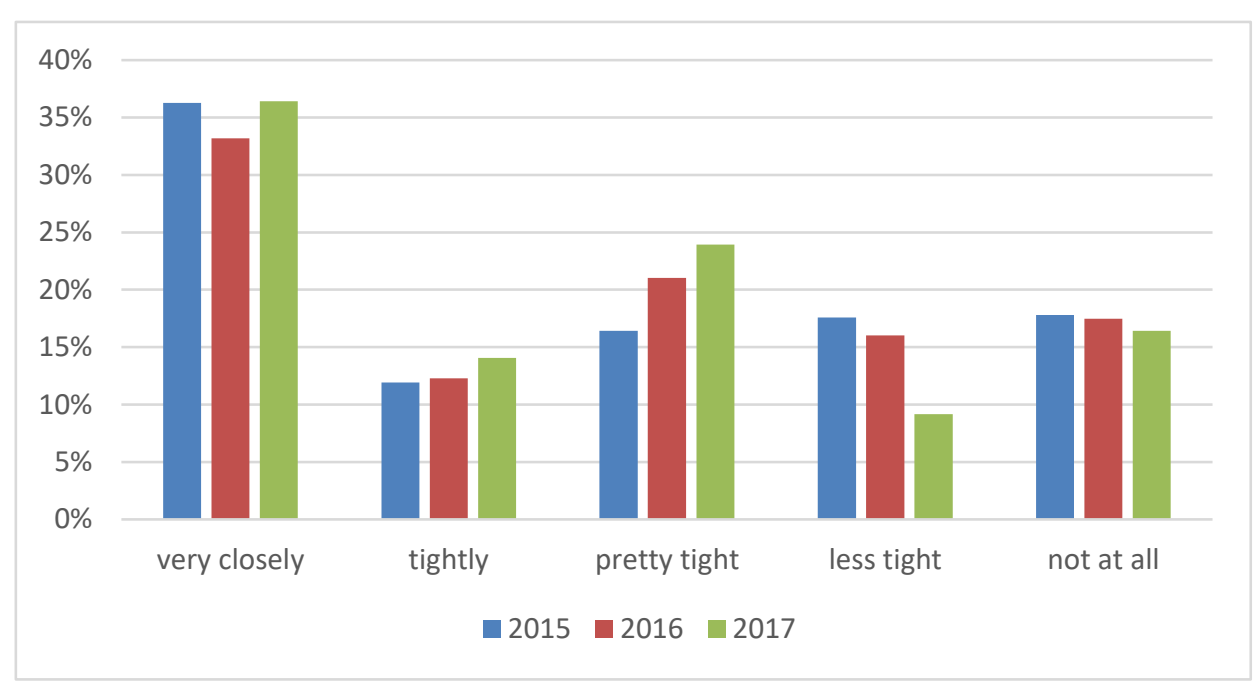

The results showed that the closeness of the relationship between fields of work and study programs showed an increasing trend from year to year. This shows that the link and match policy is proven to be effective in increasing the absorption capacity of private university graduates in the world of work. However, there is an increasing trend in occupations that are not at all related to the study program. However, this condition is in line with the increasing trend in the number of alumni who choose to become entrepreneurs. Seeing this condition, it is possible to increase the number of absorptions outside the study program, driven by the large number of alumni who pioneered various types of new businesses that are in accordance with market conditions but are not in line with their study programs during college.

\section{DISCUSSION}

Based on the 2018 data published by the government, there are 4670 universities in Indonesia, of which only 122 state universities (Nirmala et al., 2018). Then the data also shows that more than 3000 universities in Indonesia are managed by private institutions. This shows that private universities have a proportion of more than $90 \%$ of all tertiary institutions in Indonesia.

The link and match policy launched by the government since 2000 began to be evaluated in 2014 (Hasibuan, 2019) at first done in public universities. Then developed to private universities. The process of developing link and match policies in private universities in Indonesia is still ongoing today.

The link and match policy is a policy that directs the alignment or suitability of university graduates' competencies with the competencies needed by users or the world of work (Disas, 2018; Fikawati, 2018). The implementation of link and match policies in universities is evaluated through horizontal alignment and vertical alignment of graduates with the needs of the world of work (Sasongko, 2019). Alignment in this case was measured based on the results of tracking on alumni who had completed the previous 2 years of study.

The results of the data analysis show that the number of graduates who work within 2 years of graduation tends to increase over time. This condition illustrates that tertiary education graduates show consistency in quality improvement as shown by the large number of graduates accepted by the world of work. This result is reinforced by previous research which concluded that the quality of graduates can be seen from the absorption of graduates by the world of work (Moya Clemente et al., 2020; Muhson et al., 2012).

When viewed from the percentage, the number of graduates who work is getting smaller and smaller. But interestingly, the percentage of graduates who choose to become entrepreneurs tend to increase. The 
increase in the percentage of graduates who choose to become entrepreneurs in Indonesia is strengthened by the results of the Asia Pacific Entrepreneurship Survey research in April 2019 which states that $96 \%$ of Indonesians have a strong desire to become entrepreneurs(Herbalife Survey, 2019). The rationalization of the number of employees in various companies because of the outbreak of the Corona virus 19 and the economic recession, has caused many employees to be laid off and laid off to seek alternative sources of income through entrepreneurship. This has led to a drastic increase in the number of entrepreneurs in 2019 by more than 25\%. As data published by the Ministry of Manpower and the Indonesian Chamber of Commerce states that Covid19 has impacted 6 million people being laid off and 3 million laid off from their jobs (Nasution, 2020; Yunianto, 2020).

Further analysis regarding the workplace shows that private companies and government institutions are the main choice for places to work for private university graduates in Indonesia. This is in line with the vision and mission of the link and match policy, which requires synchronization of the need for labor and qualifications for college graduates. The results of the analysis show that workplaces in government agencies are the favorite choice of graduates in 2015 and 2016, although it shows a decreasing trend, even in graduates in 2017 government agencies are no longer the favorites of graduates. The decline in the trend of government institutions as a choice for work is caused by unstable economic conditions, unclear career paths and stagnant wages. So that graduates prefer to work in other places,

In contrast to government agencies, private companies have an increasing trend as the preferred workplace for private university graduates in Indonesia. The growing trend of working for private companies is due to the increasing awareness of the career centers of private universities in reducing the waiting period for graduates by increasing the amount of information on job vacancies for private companies and cooperation with private companies in the recruitment of employees. Meanwhile, the recruitment system for employees / employees in government agencies is carried out simultaneously and in a systematic manner, which causes graduates to only register at one institution at a time.

Vertical alignment is an analysis of the suitability of jobs with the level of graduate education. This analysis provides information about the competence of graduates in completing work according to their education level. The results of the analysis show that vertical alignment is experiencing an increasing trend, it can be seen from the workload requiring competence at the undergraduate level, which has a higher percentage. The increasing trend of vertical alignment shows the successful implementation of the link and match policy in private universities in Indonesia. The increasing trend of vertical alignment also shows that the quality of competency in undergraduate programs owned by private university graduates has experienced an improvement trend every year.

Horizontal alignment is an analysis of the suitability of study programs or the expertise of private higher education graduates with the competencies required by the work they are running. This alignment provides information about the suitability of graduate competencies with the competencies required by their work. The success of the link and match policy can be seen from the increasing closeness of the relationship between graduate competence and the needs of the world of work, which is indicated by the trend of increasing the percentage in the category, which is quite close, tight, and very close. This condition indicates an improvement in the competence of graduates of private universities in Indonesia in accordance with the competencies required by the world of work in society.

The effectiveness of the implementation of link and match policies in private universities is indicated by the absorption capacity, vertical alignment, and horizontal alignment of graduates. (Sasongko, 2019). The absorption capacity of private higher education graduates has increased significantly from year to year, which can be seen from the increasing number of graduates getting jobs within 2 years of graduating. Then the vertical alignment and horizontal alignment also show an increasing trend from year to year. This means that from year to year there has been an increase in the quality and quantity of competence of private higher education graduates that are absorbed by the world of work in accordance with the level of education and competence they have. Based on these discussions, it can be concluded that the implementation of the link and match policy in private universities has been effective.

This research also produces data which shows that entrepreneurship is still not a career priority for college graduates. This condition can be seen from a total of 2049 respondents who worked, there were 
$22 \%$ who chose a career as an entrepreneur. This figure is driven by a significant increase in college graduates who become entrepreneurs in the 2019 survey of graduates in 2017 . This condition is allegedly a result of the outbreak of the corona virus in early 2019 in Indonesia, which resulted in an increase in the number of employees who were laid off and the occurrence of economic recession.

\section{CONCLUSION}

Trends formed by the number and percentage of private tertiary education graduates who work in the government, private, NGO, and other sectors show a significant increase both in terms of number, vertical alignment, and horizontal alignment. This condition shows that the link and match policy that has been implemented by the government in private universities has been effective in reducing the number of unemployed people, and in increasing the compatibility of graduates' competencies with the competencies needed by the world of work.

The results also show that the choice of workplaces for university graduates is private companies, government agencies, and then social institutions. While entrepreneurship is still not a priority choice for graduates in work, although there is a tendency to increase from year to year.

\section{RESEARCH LIMITATIONS}

Based on the research method, there are several limitations that can be identified as follows: 1) the research sample is small, when compared to all graduates of private universities in Indonesia, 2) The study was conducted on respondents outside Java Island, which is the main island in Indonesia with better education quality, 3) some respondents did not fill out the questionnaire completely, so as to reduce the bias the percentage of research results was based on the number of each questionnaire answered by the respondent, 4) the sample was taken by snowball random sampling regardless of the origin of the college, province, and islands, which cause disproportionate representation of private universities in Indonesia.

\section{SUGGESTION}

Based on the results of this study, private universities need to collaborate with various private companies in preparing curriculum and learning activities to meet the needs of the labor market. In addition, private universities also need to improve the soft skills and life skills of graduates, so that they can think innovatively, adaptively, and be a solution to future problems.

\section{REFERENCES}

Ahmad, I. (2017). Surat Edaran Pelaksanaan Tracer Study di Perguruan Tinggi. Retrieved from http://kopertis3.or.id/v2/wp-content/uploads/Surat-Edaran-TS.pdf

Alam, S. (2016). Tingkat Pendidikan dan Pengangguran di Indonesia (Telaah Serapan Tenaga Kerja Sma/Smk dan Sarjana). Jurnal Ilmiah Bongaya, pp. 250-257. Retrieved from https://ojs.stiembongaya.ac.id/index.php/JIB/article/view/19

Badan Pusat Statistik. (2019, March). Open Unemployment by Highest Education Graduated 1986-2021. Retrieved from https://www.bps.go.id/statictable/2009/04/16/972/pengangguran-terbukamenurut-pendidikan-tertinggi-yang-ditamatkan-1986---2019.html

Disas, E.P. (2018). Link and Match sebagai Kebijakan Pendidikan Kejuruan. Jurnal Penelitian Pendidikan, 18(2), 231-242. Retrieved from https://ejournal.upi.edu/index.php/JER/article/view/12965

DSN Staff. (2019, June 20). Herbalife Survey: 7 in 10 People in Asia Pacific Aspire to Be Business Owner. Direct Selling News. Retrieved from https://www.directsellingnews.com/herbalifesurvey-7-in-10-people-in-asia-pacific-aspire-to-be-business-owner/ 
Enders, J., \& Teichler, U. (1997). A victim of their own success? Employment and working conditions of academic staff in comparative perspective. Higher Education, 34(3), 347-372.

https://doi.org/10.1023/A:1003023923056

Fikawati, S. (2018). PROGRAM-PROGRAM: PUSAT KARIR PERGURUAN TINGGI [Powerpoint]. Seminar Pengembangan Pusat Karir dan Pusat Karir Lanjutan (Tracer Study), Jakarta. Retrieved from http://kopertis3.or.id/v5/wp-content/uploads/FUNGSI-DAN-MANAJEMEN-PUSATKARIR-2018.pdf

Hasibuan, Z.A. (2019, September). Link and Match Kesenjangan Kualitas dan Kuantitas SDM Lokal sesuai dengan Kebutuhan Industri [Powerpoint]. FGD Menyiapkan Talenta Digital Lokal Siap Kerja, Siap Wirausaha, Jakarta. Retrieved from http://www.wantiknas.go.id/wantiknasstorage/file/img/materi/2019/Oktober/Link\%20and\%20Match\%20Kesenjangan\%20Kualitas.pdf

IIEP-UNESCO. (2015, June 16). Higher education and the world of work: What's the evidence behind educational policies? Retrieved from http://www.iiep.unesco.org/en/higher-education-and-worldwork-whats-evidence-behind-educational-policies-3197

Kogan, M., \& Brennan, J. (1993). Higher Education and the World of Work: An Overview. Higher Education in Europe, 18(2), 2-23. https://doi.org/10.1080/0379772930180202

Moya Clemente, I., Ribes Giner, G., \& Sanahuja Vélez, G. (2020). Towards Sustainability in University Education. Improving University Graduates Chances of Employability by Participation in a High Achievement Academic Program. Sustainability, 12(2), 680. https://doi.org/10.3390/su12020680

Muhson, A., Wahyuni, D., \& Mulyani, E. (2012). ANALISIS RELEVANSI LULUSAN PERGURUAN TINGGI DENGAN DUNIA KERJA. Jurnal Economia, $8,11$.

Nasution, A.D. (2020, June 12). Menaker Sebut 3 Juta Pekerja Dirumahkan dan Kena PHK Imbas Corona. Katadata.co.id. Retrieved from https://katadata.co.id/ameidyonasution/berita/ 5ee33f108fef5/menaker-sebut-3-juta-pekerja-dirumahkan-dan-kena-phk-imbas-corona

Nirmala, I., Attamimi, A.N.R., \& Alami, V.E. (2018). Statistik Pendidikan Tinggi Indonesia 2018 (Stats PT 18; Statistik Pendidikan Tinggi Tahun 2018, p. xvi + 220). Kementerian Riset Teknologi dan Pendidikan Tinggi. Retrieved from https://pddikti.kemdikbud.go.id/asset/data/publikasi/ Statistik\%20Pendidikan\%20Tinggi\%20Indonesia\%202018.pdf

Robst, J. (1995). Career Mobility, Job Match, and Overeducation. Eastern Economic Journal, 21(4), 539550. JSTOR. Retrieved from https://www.jstor.org/stable/40325672

Sasongko, D. (2019). Peraturan Badan Akreditasi Nasional Indonesia. Retrieved from https://www.banpt.or.id/wp-content/uploads/2019/10/Peraturan-BAN-PT-No.-5-Tahun-2019Instrumen-APS-1.pdf

Supriati, S., \& Handayani, T. (2018). RELEVANSI LULUSAN PERGURUAN TINGGI DALAM PENEMPATAN KERJA. Journal of Applied Business Administration, 2(2), 218-227. https://doi.org/10.30871/jaba.v2i2.1121

Teichler, U. (1999). Research on the relationships between higher education and the world of work: Past achievements, problems and new challenges. Higher Education, 38(2), 169-190. https://doi.org/10.1023/A:1003761214250

Yunianto, T.K. (2020, June 7). Kadin Sebut 6 Juta Pekerja Dirumahkan dan Kena PHK akibat Pandemi. Nasional Katadata.co.id. Retrieved from https://katadata.co.id/ameidyonasution/berita/5edcfd08aeffa/kadin-sebut-6-juta-pekerjadirumahkan-dan-kena-phk-akibat-pandemi 